International Review of Social History 44 (1999), pp. 419-449

(C) 1999 Internationaal Instituut voor Sociale Geschiedenis

\title{
Social Mobility and Class Formation: The Worklife Social Mobility of Men in a New Zealand Suburb, I9O2-I928
}

\author{
ERik Olssen and Hamish James
}

Summary: This paper explores the relationship between social mobility and class formation in a working-class industrial suburb. By establishing the degree of class closure in three periods we can identify the relationship between the country's political history, dominated by the rise of a left-wing Labour Party, and the changing levels of closure. Labour established itself during a period of low mobility then stalled when mobility increased sharply in the I920s. Comparison with the mobility rates for cities in other countries allows further analysis of the relationship between social structure and political behaviour. Our evidence indicates that voters were not unconscious of the shifting patterns of class rigidity.

New Zealanders had long believed that New Zealand was more egalitarian than the Old World and provided greater opportunities for the common man (if not the common woman). The American belief in "rags to riches" did not exist and the downward fall from "riches to rags", from aristocratic rank in Britain to a menial position in the colony, attracted much more interest. $^{2}$ Even the idea of equality of opportunity has rarely been proclaimed, partly (no doubt) because of the widespread belief that everyone is more on a level, and the equally widespread desire to live in a society with

I. In the course of its gestation this paper has benefited from those working on "Urban Society and the Opportunity Structure" (part of an ongoing inquiry known as the Caversham Project), headed by Professor Erik Olssen and funded by the Foundation for Research, Science and Technology: Tom Brooking, Dick Martin, David Thomson, and especially Clyde Griffen. More information on the Caversham Project can be found at http://www.otago.ac.nz/history/caversham. We are also grateful to Professor Miles Fairburn, Dr David Pearson, and Dr Peter Davis for their comments on a previous draft, and to Professor Frank Jones, Research School of Social Sciences at the Australian National University, and Mr Brian Niven of the Centre for Application of Statistics and Mathematics (CASM), University of Otago, for guidance on log-linear modelling. The journal's three anonymous readers also provided most helpful criticisms.

2. Although there is no good historical study of the phenomenon, in the late nineteenth century New Zealanders were especially fascinated with "remittance men", as they were known - i.e. men of superior families sent to the colony and regularly provided with a remittance to save them from utter humiliation; see Nell Hartley, Colonial Outcasts: A Search for the Remittance Men (Morrinsville, NZ, 1993). 

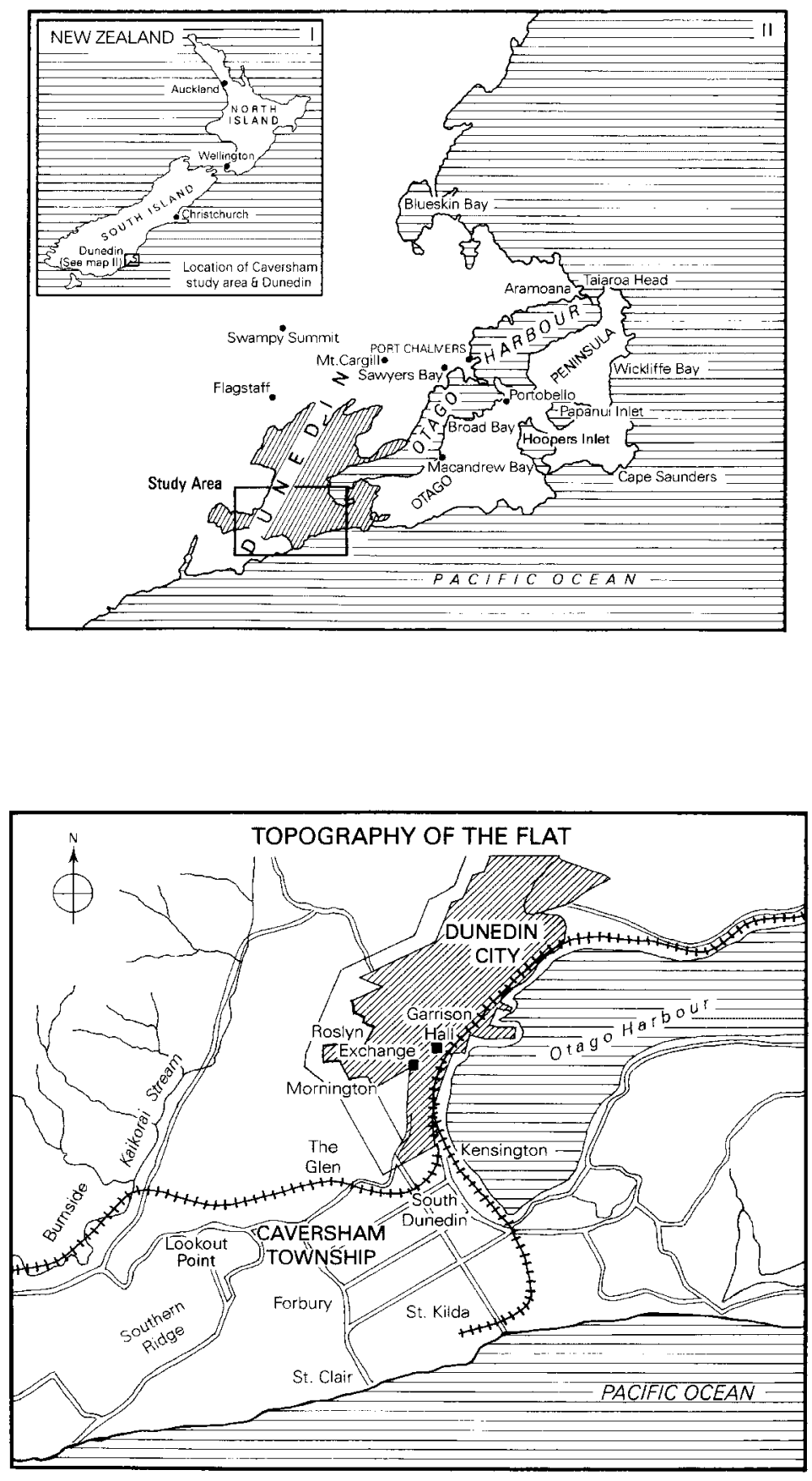

Figure I. Maps showing the location of Caversham, New Zealand. 
no very rich and no very poor. This may explain why there have been few mobility studies in New Zealand, either by social historians or sociologists. ${ }^{3}$ W.H. Oliver, in denying the role of social class in New Zealand's history, pointed to the short expanse from the social floor to the ceiling. ${ }^{4}$ Oliver also insisted that class was not important because it had usually been so easy for men to move upwards in society by acquiring education, land, or capital. Others have agreed. Miles Fairburn, in a series of works, has explained the conservatism of New Zealand society by reference to the high levels of upwards social mobility (although in later work he placed more emphasis on transience). ${ }^{5}$ Not all scholars have accepted the OliverFairburn argument, but there has been a broad consensus that upwards mobility has weakened class consciousness in New Zealand. ${ }^{6}$ Even if we accept this argument - and this study is designed to test it - two possibilities have been ignored: first, that high macro-levels of upwards mobility are not necessarily incompatible with a strong tradition of class consciousness; ${ }^{7}$ and second, that high levels of upwards mobility since the I850s may have underwritten the social consensus about the desirability of the welfare state which emerged in many capitalist societies this century.

In the I960s and I970s studies of social mobility were a major scholarly industry in the United States, where it had long been believed that the

3. Apart from the recent work by F.L. Jones and Peter Davis, Models of Society: Class, Stratification and Gender in Australia and New Zealand (Sydney and London, 1986), most of the research is summarized in David Pitt (ed.), Social Class in New Zealand (Auckland, NZ, 1977), and especially Cora Vellekoop Baldock's chapter, "Occupational Choice and Social Class in New Zealand", pp. 78-98. David Pearson's Johnsonville: Continuity and Change in a New Zealand Township (Sydney, NSW, 1980), pp. I06-I20 is the major study of historical evidence, but he used marriage certificates. See also David G. Pearson and David C. Thorns, Eclipse of Equality: Social Stratifcation in New Zealand (Sydney, NSW, 1983), ch. 5.

4. W.H. Oliver, "Reeves, Sinclair and the Social Pattern", in Peter Munz (ed.), The Feel of Truth: Essays in New Zealand and Pacific History (Wellington, NZ, 1969), pp. 163-180. Margaret Galt demonstrated conclusively how short this expanse has been; see "Wealth and Income in New Zealand, c. 1870-c.1939", (Ph.D. thesis, Victoria University of Wellington, NZ, 1985).

5. Miles Fairburn, "Social Mobility and Opportunity in Nineteenth-Century New Zealand", New Zealand Journal of History, I3 (1979), pp. 43-60, and "Why Did the New Zealand Labour Party Fail to Win Office until I935?”, Political Science, 37 (1985), pp. IOI-I24, are the most important. He has restated his central argument in The Ideal Society and its Enemies: The Foundations of Modern New Zealand Society, I850-I900 (Auckland, NZ, 1989). His intriguing analysis of the diaries of James Cox, Nearly Out of Heart and Hope: The Puzzle of a Colonial Labourer's Diary (Auckland, NZ, 1995), modifies this optimistic view. For our assessment of Fairburn's argument see Tom Brooking, Dick Martin, David Thomson and Hamish James, "The Ties That Bind: Persistence in a New World Industrial Suburb, 1902-22”, Social History, 24 (1999), pp. 53-73.

6. Following Fairburn, recent historical studies of mobility have focused on the issue of "transience", ignoring the chronological specificity of The Ideal Society and its Enemies. See the special issue of New Zealand Journal of History, 25 (1991).

7. Erik Olssen explored that possibility in The Red Feds: Revolutionary Industrial Unionism and the New Zealand Federation of Labour, I908-19I4 (Auckland, NZ, 1988), and Building the New World: Work, Politics and Society in Caversham, I880s-1920s (Auckland, NZ, 1995). 
New World generated greater equality than existed in the Old World. ${ }^{8}$ One important dimension of equality in the United States, perhaps the most important, has long been the existence of equality of opportunity. According to this belief men could frequently and easily proceed from rags to riches. Despite the centrality of this belief, only in the 1960s did historians try to measure the extent of social mobility. The absence of similar studies for other societies meant that American scholars often concluded that although social mobility was less than once believed it must still have been "higher" than elsewhere. Several concluded that the "high" level of upwards mobility discovered in various communities helped contribute to the weakness of class consciousness in the United States and the absence of a popular party of the "left". ' The American studies assumed that the level of social mobility defined the permeability of class boundaries (a central proposition in the Weberian tradition); high mobility means weak class boundaries, a reduced possibility for class consciousness, and a lower likelihood of class-based political action. These conclusions attracted considerable criticism, not least because they ran contrary to the main thrust of social history's preoccupation with collective behaviour and shared experience. ${ }^{\mathrm{IO}}$ As Clyde and Sally Griffen remarked, however,

If there is an inherent danger that mobility studies will overemphasize the individual drive for success, there is also a corresponding danger that the interests of historians of labour or immigration in the occasions when their subjects express

8. Ironically, this thesis was first fully developed by Stephan Thernstrom and others after Seymour Martin Lipset and H.L. Zetterberg had adduced considerable evidence to contradict the view that the United States was more open to upwards mobility; see "Social Mobility in Industrial Societies", in Lipset and Reinhard Bendix, Social Mobility in Industrial Society (Berkeley and Los Angeles, CA, 1959).

9. The major historical works are Stephan Thernstrom's two monographs, Poverty and Progress: Social Mobility in a Nineteenth-Century City (Cambridge, MA, 1964) and The Other Bostonians: Poverty and Progress in an American Metropolis 1880-1970, (Cambridge, MA, 1973). See also Thernstrom's essay, "Socialism and Social Mobility", in John H.M. Laslett and S.M. Lipset (eds), Failure of a Dream: Essays in the History of American Socialism (New York, 1974), pp. 509-55I. There have also been several major studies of North American towns in the mid-nineteenth century, notably Michael B. Katz, The People of Hamilton, Canada West: Family and Class in a Mid-Nineteenth Century City (Cambridge, MA, 1976); Clyde and Sally Griffen, Natives and Newcomers: The Ordering of Opportunity in Mid-Nineteenth-Century Poughkeepsie (Cambridge, MA, 1978); Michael B. Katz, Michael J. Doucet and Mark J. Stern, The Social Organization of Early Industrial Capitalism (Cambridge, MA, 1982); and Stuart M. Blumin, The Emergence of the Middle Class: Social Experience in the American City, I760-I900 (Cambridge, MA, 1989).

Io. The criticisms are well summarized in Margo Anderson Conk, The United States Census and Labor Force Change: A History of Occupational Statistics, I870-1940 (Ann Arbor, MI, 1978), pp. 7I73, and Patrick M. Horan, "Occupational Mobility and Historical Social Structure", Social Science History, 9 (1985), pp. 30-33. Erik Olssen addressed Thernstrom's most disputed conclusion but without dismissing the relevance of his work in "The Case of the Socialist Party Which Failed, or Further Reflections on an American Dream", Labor History, 29 (1988), pp. 416-449. 
solidarity will lead [...] [them] to overlook the simultaneous presence of individual aspirations $[\ldots]$. $^{\text {II }}$

In the United States urban historians, having made a considerable impact, retreated. The criticisms of their assumptions, methods and conclusions, in particular those conclusions which inferred action/consciousness from structural patterns, doubtless made the tedium and labour necessary for such work seem pointless. By the early I980s the study of social mobility was regarded (by most historians) as an intellectual dead end; it was even described as “'deep in the throes of Thermidorian reaction' against its quantitative models and methods" ${ }^{\text {I2 }}$ Ironically, as Grusky and Fukumoto point out, within the discipline of sociology the "subfield of mobility analysis has [...] flourished during this period [...] transformed by the development of new models, new conceptual orientations, and new theoretical perspectives". In particular, the application of log-linear modelling to studies of mobility made it possible to control for demographic and occupational change. As a result, the common criticisms of the "new" urban history and its mobility studies have been met. ${ }^{13}$

While many sociologists and historians are repelled by the complexities of log-linear modelling, a number of European historians have begun to tackle worklife and intergenerational mobility. ${ }^{\text {I4 }}$ Inspired by the work of John E. Goldthorpe et al., particularly Social Mobility and Class Structure in Modern Britain (1990) and The Constant Flux (1992), a major comparative study of social mobility co-authored with R. Erikson, several scholars have tackled the problem of measuring past patterns and rates of social mobility. These studies adopted Goldthorpe's "class-structural” method of conceptualizing the occupational structure and deployed sophisticated statistical methods to analyse the occupational information about historical populations contained in various historical sources, notably marriage records (which usually record the occupations of the groom and his father). Marriage records have proved attractive because they provide historians with a source akin to the national representative samples from which sociologists generate survey data but, like survey data itself, the limitations of the source

II. Clyde and Sally Griffen, Natives and Newcomers, pp. xii-xiii.

I2. K.N. Conzen, "Quantification and the New Urban History", Journal of Interdisciplinary History, I3 (1983), p. 654, cited by David B. Grusky and Jean K. Fukumoto, "Social History Update: A Sociological Approach to Historical Social Mobility”, Journal of Social History, 23 (I989), p. 22I. 13. Ibid., pp. 22I-232.

I4. See Andrew Miles and David Vincent (eds), Building European Society: Occupational Change and Social Mobility in Europe I840-1940 (Manchester, I993); Mike Savage, "Social Mobility and Class Analysis: A New Agenda for Social History?”, Social History, 19 (1994), pp. 69-79; and Marco H.D. Van Leeuwen and Ineke Maas, "Social Mobility in a Dutch Province, Utrecht I850I940”, Journal of Social History, 30 (1997), pp. 619-644. For an overview of recent work in Europe and the United States, see idem, "Long-Term Social Mobility: Research Agenda and a Case Study, Berlin I825-1957”, Continuity and Change, II (1996), pp. 399-433. 
have prompted several criticisms. ${ }^{15}$ Most notably, as A.B. Sørenson pointed out, marriage records suffer from the problem of any "two-point analysis" (i.e. a snapshot of the father's and the son's occupations on the day when the marriage record was filled out). ${ }^{16}$ National representative samples also tend to overlook unusual or atypical groups, ignore the possible importance of local context as a dimension of the stratification order, and make it difficult to disaggregate "conventional aggregate classes". "Although local stratification is often regarded as sociologically trivial," as Grusky and Sørensen recently pointed out, "the available evidence suggests that such class analytic processes as closure, exploitation, and collective action emerge more clearly at the level of disaggregate occupations than conventional aggregate classes. ${ }^{\text {"17 }}$ No method is without problems or critics but each can help reveal the processes and rates of social mobility which "bear centrally on class formation, class structuration, and the potential for class action". ${ }^{18}$ Mobility, in short, is a "crucial mediating process" between structure and action. ${ }^{\text {I9 }}$

\section{THE CAVERSHAM PROJECT}

The Caversham project was undertaken to assess some of these issues and to provide a basis of comparison with other studies. ${ }^{20}$ Caversham is an urban-industrial suburb of the country's then most industrial city, Dunedin. Although in the period studied, $1902-1928$, Dunedin was beginning to decline (relative to other cities in New Zealand), it continued to grow in absolute terms (from 46,515 at the I90I Census to an estimated 84,060 by 1928). ${ }^{21}$ During the period studied Caversham comprised roughly twelve per cent of Dunedin's population and the occupational structure remained a microcosm of that for urban New Zealand as a whole. The population turned over rapidly, often moving short distances to adjacent suburbs, with almost seventy per cent of the adult population resident in the suburb for less then ten years. Inflow exceeded outflow, but both

I5. For a judicious discussion of these problems and the various alternative approaches see Mike Savage, "Social Mobility and the Survey Method: A Critical Analysis", in Daniel Bertaux and Paul Thompson (eds), Pathways to Social Class: A Qualitative Approach to Social Mobility (Oxford, 1997), pp. 299-326. The other essays in this volume explore alternative approaches.

I6. A.B. Sørenson, "Theory and Methodology in Social Stratification", in U. Himmelstrand (ed.), Sociology from Crisis to Science (London, 1986), pp. 69-95.

17. David B. Grusky and Jesper B. Sørensen, "Can Class Analysis Be Salvaged?”, American Journal of Sociology, I03 (1998), p. II87.

I8. Jones and Davis, Models of Society, p. I2.

19. Erikson and Goldthorpe, Constant Flux, p. 2.

20. For a fuller account of the project and the main sources used see Erik Olssen et al., "Urban Society and the Opportunity Structure in New Zealand: The Caversham Project", Social History, 24 (1999), pp. 39-54.

21. New Zealand Official Year Book, (Wellington, NZ, 1902), p. 213 and 1929, p. 100. 


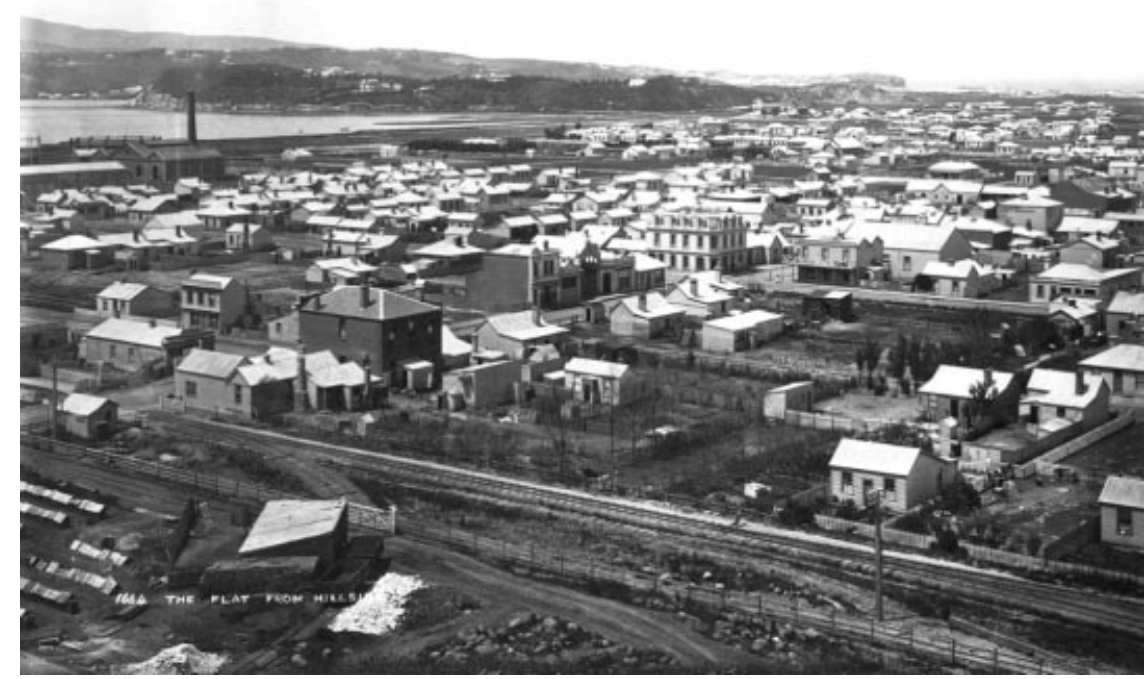

Figure 2. The Flat from the Hillside. This photograph was taken of the most densely populated part of Caversham Borough just before the beginning of the period studied. As can be seen, the area was dominated by a small number of two-storied buildings, usually shops or workshops, and a lot of small cottages situated on their own plots of land. The gasworks, the railway workshops, a substantial brick works and a flourmill dominated this part of the Borough and manual workers inhabited the cottages.

Otago Settlers' Museum

migration streams were random, and the occupational structure of the suburb remained remarkably stable. ${ }^{22}$ The state-owned railway workshops, several large engineering workshops and foundries, a boot-making factory, a brick works and a sanitary-pipe factory were the major employers. A high proportion worked in small-scale enterprises. ${ }^{23}$

Unfortunately, the enumerator's returns from the New Zealand census have been destroyed, forcing social historians to rely on other sources. The electoral rolls are the best available source because they recorded all members of both sexes who, having arrived at the age of twenty-one and being of sound mind etc., registered to vote in a general election. With the exception of the First World War, when the government extended Parliament's life, elections were held every three years. The electoral rolls have proved surprisingly comprehensive. The I90I New Zealand Census gives an adult

22. See Tom Brooking, Dick Martin, David Thomson, and Hamish James, "The Ties That Bind: Persistence in a New World Industrial Suburb 1902-1922", Social History, 24 (1999), Table I, p. 9. 23. There were also a flour mill, a large joinery factory, a boot-making factory and several smaller industries, including a gasworks and a rope manufactory; for a fuller account of the community see Olssen, Building the New World, ch. 3. 
population for the borough of 2,986, and in 19022,945 adults registered to vote. ${ }^{24}$ Despite their comprehensiveness the electoral rolls impose some constraints on this analysis. This source only provides occupations for men, presumably the occupation identified by the voter, and women were identified by their marital status. Nor do the electoral rolls indicate status (e.g. a baker could be an apprentice, journeyman, master, or large employer). In order to determine status we used a street directory, John Stone's Directory for Otago and Southland. Although less comprehensive than the electoral roll, the directory provides an almost complete list of all trades, professions and businesses. ${ }^{25}$

The most important limitation of the electoral rolls is that they only allow analysis of intra-generational mobility of men, now usually referred to as worklife mobility. The nature of our data means that we have investigated the mobility turnover of a suburb rather than worklife mobility as traditionally understood. In other words we are not primarily analysing "the mobility trajectories of individuals but rather [...] mobility rates and patterns understood as societal attributes". ${ }^{26}$ Our sources allow us to establish the extent to which each social class recruited from its own ranks, how open this urban-industrial society was across this prosperous period (albeit one characterized by high levels of industrial conflict and class mobilization), and whether it was in any respects exceptional. ${ }^{27}$ We can thus determine the degree of "demographic class formation" by analysing occupational mobility in Caversham within a comparative perspective.

It has long been recognized by students of mobility that occupational mobility is not a surrogate for social mobility. Occupational mobility ignores changes in residence, income, wealth, education and lifestyle. Nor are the changes in occupation addressed in this paper necessarily the only important changes. Occupational change did not necessarily entail a shift in social class although it may well have involved a rise in income, an increase in autonomy, or an improved lifestyle. Besides, in large organizations, such as the railways or a bank, substantial career mobility might be achieved without a change in class. ${ }^{28}$ Students of social mobility also now

24. I9OI is the last time Caversham appears separately in the census because the ratepayers voted to amalgamate with Dunedin City before the next census.

25. For a full account of the classification and appendices listing all occupations and their classifications, see Erik Olssen and M. Hickey, "Towards an Occupational Classification for Urban New Zealand, I9OI-I926”, and for the classifications Appendices A and B, Caversham Working Paper, I996-3, and "The Local and the National: An Occupational Classification for Caversham", Caversham Working Paper, 1998-4.

26. Erikson and Goldthorpe, Constant Flux, p. 306.

27. A.B. Sørenson, "Theory and Methodology in Stratification Research", in Himmelstrand (ed.),

The Sociology of Structure and Action, vol. I, p. 78.

28. See for instance David Vincent, "Mobility, Bureaucracy And Careers In Early Twentieth-

Century Britain", in Miles and Vincent (eds), Building European Society, pp. 217-218, and the various methods used in Bertaux and Thompson (eds), Pathways to Social Class. 
recognize that not everyone wanted occupational mobility, but it is possible to make reasonable inferences from mobility patterns about the degree of class cohesion, the extent of affinity or disaffinity between classes, classrecruitment patterns, whether particular occupations or classes had distinctive attitudes, and "demographic class formation". ${ }^{29}$ In short, occupation remains the most accessible detail concerning everybody living in New Zealand society in a previous period. Knowing somebody's occupation also allows us, with varying degrees of accuracy, "to know how good a living he earns, how much education he had before leaving school, what kind of dwelling and what kind of neighbourhood he lives in [...]. Occupation is bighly correlated with other social variables in any modern industrial society." ${ }^{30}$

Two constraints have controlled the precise form of occupational classification adopted. First, we wanted to ensure that whatever categories we developed for analysing occupational mobility in Caversham were comparable with those used by scholars in other societies. Second, the desire for comparability with studies of other societies had to be modified in order to ensure that the system of classification we adopted was faithful to the local evidence and allowed for disaggregation. Consequently we decided that more categories were needed than most studies have used and that we would investigate, not assume, the centrality of the divide between "white-collar" and "blue-collar" occupational classes. ${ }^{3 \mathrm{I}}$ We established a separate category for small employers and the self-employed (the US Census data does not permit this distinction to be used but sociological studies usually observe it). ${ }^{32}$ As remarked earlier, Stone's Directory proved indispensable in this process. This provides a degree of refinement in classification which historians elsewhere have sometimes lacked. ${ }^{33}$ It is possible, however, to aggregate our categories to match those used in the United States and, to a lesser extent, western Europe. It ought to be said, however, that "it is an empirical matter

29. For a judicious discussion see the Griffens, Natives and Newcomers, ch. 2, and Mike Savage, "Social Mobility and Class Analysis", pp. 69-79.

30. Thernstrom, Other Bostonians, p. 46. There is a large sociological literature which confirms this point although some evidence suggests that the smallness of New Zealand society has made complexity more central; see Pitt (ed.), Social Class in New Zealand, and more especially Pearson and Thorns, Eclipse of Equality, pp. 244-247, which analyses "small-town capitalism" and its social relations.

31. Nine categories were used (as against Thernstrom's five). David G. Pearson and David C. Thorns, Eclipse of Equality, p. 23I, summarized several studies which used "white-collar" and "manual" as a critical divide by concluding that while "the inheritability of a blue or white collar is [...] strikingly high [...] short range moves between low white-collar and skilled manual [...] were common".

32. Erikson and Goldthorpe, Constant Flux, p. 36.

33. Clyde and Sally Griffen, Natives and Newcomers, p. 55, are an exception and used the directories for Poughkeepsie to identify journeymen and masters. For a discussion of the importance of the distinction in Caversham see Olssen, Building the New World, ch. 3. 
to see how many social classes are actually formed in any society". One object of this study is to determine the degree to which the structural (or economic) classes were self-contained and separate from the others, as measured by traffic between each pair, or (in other words) the degree to which these structural classes were also social classes. ${ }^{34}$

The class categories used will be broadly familiar to students of mobility (a broad Marxist schema based on relationship to the means of production with Weberian labour market criteria to introduce more refined distinctions). ${ }^{35}$ The classes are as follows:

(I) large employers and higher managerial;

(2) professionals;

(3) semiprofessionals;

(4) small employers and self-employed, sometimes referred to as petty proprietors;

(5) officials and supervisory;

(6) "white-collar";

(7) skilled;

(8) semiskilled; and

(9) unskilled.

Two further categories were added to accommodate those who had no occupation, married women and retired men, but these categories are irrelevant to this study of male social mobility.

Within the nine structural classes we started by assuming that a threefold hierarchical division existed, based on prestige or general desirability. Large employers/higher managerial, professionals and semiprofessionals enjoyed the highest status positions in the occupational structure; "white-collar", officials and supervisory people occupied the middle ranges; and the manual workers occupied the lower status levels. The self-employed and small employers greatly complicated this hierarchical division, however. Although all mobility studies elsewhere classify them in the middle range as lower white-collar or lower middle-class the Caversham evidence problematizes that solution. Masters and journeymen dominated most trades in Caversham. Apprenticeship remained the customary requirement for entry;

34. The quotation and the distinction are from Mike Savage, "Social Mobility and Class Analysis", Social History, in (1994), p. 73.

35. The justification for this approach is spelt out in Olssen and Hickey, "Towards an Occupational Classification", pp. I-I2 and the problems involved in applying this scheme to the data are discussed in the rest of that working paper. J.H. Goldthorpe's Introduction to Social Mobility and Class Structure in Modern Britain, (Oxford, 1986), provides an excellent overview of the literature relating to social class. Although Goldthorpe's pragmatic approach to class - which he defines as an issue to be empirically investigated - has been attacked, we feel that the attack has been unsuccessful, as do others; see Richard Breen and David Rottman, "Class Analysis and Class Theory", Sociology, 29 (1995), pp. 453-473. 
Table I.I Occupational mobility of men in Caversham

(a) Nine-class model

\begin{tabular}{lccc}
\hline Occupational mobility & $1902-1911$ & $1911-1919$ & $1919-1928$ \\
\hline Up (\%) & 11.0 & 4.8 & 17.8 \\
Stable (\%) & 83.9 & 90.2 & 70.8 \\
Down (\%) & 5.2 & 5.0 & 11.4 \\
\hline Number & 502 & 815 & 726 \\
\hline
\end{tabular}

(b) Three-class model

\begin{tabular}{lccc}
\hline Occupational mobility & $1902-1911$ & $1911-1919$ & $1919-1928$ \\
\hline Up (\%) & 7.0 & 2.6 & 10.6 \\
Stable (\%) & 89.4 & 94.2 & 85.0 \\
Down (\%) & 3.6 & 3.2 & 4.4 \\
\hline Number & 501 & 815 & 726 \\
\hline
\end{tabular}

masters had invariably served apprenticeships and had worked as journeymen, and craft culture was more important than class in most areas of cultural and social life (including politics for the first part of the period). ${ }^{36}$ Nor did manual workers accept that white-collar or supervisory occupations enjoyed higher prestige. Many manual workers took offence when the Arbitration Court classified them as unskilled. ${ }^{37}$ Whatever we assume about occupational prestige, however, no assumption can be made about a hierarchy of power, property or wealth although members of the "elite" classes would usually have possessed more of each than anyone in the manual working classes..$^{38}$ In this paper, in short, mobility is largely conceptualized within a nine-class structure although the nine classes can be grouped in a threefold social hierarchy - upper non-manual, middle (including small employers and the self-employed), and manual working classes.

\section{OCCUPATIONAL MOBILITY}

Table I.I reveals the broad pattern of social mobility in three time periods (those there in 1902 and I9II, I9II and 1919, and I919 and 1928). Two points need to be remembered. First, the occupationally mobile in each period

36. Olssen, Building the New World, chs 3, 7 and 8.

37. I have discussed this briefly at the national level in Olssen, The Red Feds, pp. 90, 97 and idem, Building the New World, pp. 244-245.

38. See Pearson, Johnsonville, and Pearson and Thorns, Eclipse of Equality, chs 3-5 and 9; and Jim McAloon, "Colonial Wealth: the Rich in Canterbury and Otago I890-I9I4", (Ph.D. thesis, Otago University, 1993), and "The Colonial Wealthy in Canterbury and Otago: No Idle Rich", New Zealand Journal of History, 30 (I996), pp. 43-59. 
consist of different men, although I47 were present in I9O2, I9II, I9I9 and 1928. Second, Caversham's class structure remained remarkably stable across the entire period, although changes occurred in the nation's urban occupational structure, notably a marked increase in white-collar jobs and a dramatic decrease in unskilled occupations. ${ }^{39}$ Downwards mobility remained constant over the first two periods and then more than doubled to II.4 per cent on the nine-class model. The much lower rate on the three-class model for the 1919-1928 period shows that much of the movement was to adjacent classes. By contrast, upwards mobility fell sharply over the first two periods on both models, but rose substantially in the third one. As a result overall class persistence rose slightly between 1902-191I and I9II-1919 although there were considerable variations between classes. In the third period, I919I928, class persistence (those remaining in the same class) fell sharply, however, and the proportions upwardly and downwardly mobile increased. It is clear from a comparison of the nine-class and three-class models for the 1919-1928 period that much of the additional movement was between adjacent classes. Analysis of the subperiods of analysis, the inter-election periods, suggests that the First World War was a period of particularly low mobility. Following the armistice mobility increased sharply, initially to adjacent classes within each of the three hierarchical groups and then more generally.

Before analysing the most dramatic change, the increase in overall mobility following the war, the decrease in upwards mobility which occurred between I902-I9II and I9II-I9I9 requires further analysis; in order to capture the maximum detail we will use the nine-class model. Inflow and outflow percentages are shown for these periods below in Tables I.2 and I.3, and I.4 and I.5 respectively (inflow movement measures recruitment, the number of men in a class at the end of a period who had been in another class at the beginning of that period, whereas outflow movement measures class persistence or retention, i.e. the number of men who began a period in one class but had moved to another by the end of the period)..$^{40}$ These tables give an overall picture of mobility in the first two periods and they also provide three snapshots: first, reading the outflow percentages from left to right shows class destinations (i.e., where those present in 1902 were in I9II, and where those present in I9II were in I919); second, reading the inflow percentages down the columns allows one to identify the origins (i.e, where those present in I9II or 1919 had been in 1902 or I9II); and third, subject to the previous caveats, these tables also show the downwardly

39. In New Zealand as a whole, by contrast, the "white-collar" class expanded dramatically and professional/semiprofessional slightly but we do not have valid figures for Dunedin (Caversham's larger urban area); for the New Zealand occupational structure see Erik Olssen, "Towards a New Society", in Geoffrey W. Rice (ed.), The Oxford History of New Zealand (Auckland, NZ, 1992), pp. $272-276$.

40. For all the inflow and outflow tables the percentage figures have been rounded to the nearest per cent, and values less than 0.5 per cent have not been shown. 
Table I.2. Male occupational mobility in Caversham I902-I9II, outflow percentages

\begin{tabular}{|c|c|c|c|c|c|c|c|c|c|c|c|}
\hline Row \% & 1911 & & & & & & & & & & \\
\hline 1902 & $\mathrm{LE}$ & PR & SP & SE & $\mathrm{PO}$ & WC & SK & SS & US & Total & $N$ \\
\hline Large employer & 91 & & & & 4 & & 4 & & & 100 & 23 \\
\hline Professional & & 82 & & 9 & & & 9 & & & 100 & 11 \\
\hline Semiprofessional & & & 83 & & & 17 & & & & 100 & 6 \\
\hline Small employer & & & & 91 & 1 & & 7 & & 1 & 100 & 76 \\
\hline Petty official & & & & & 71 & & 29 & & & 100 & 7 \\
\hline White-collar & 1 & 5 & 1 & 9 & & 77 & 3 & 1 & 3 & 100 & 79 \\
\hline Skilled & & 1 & 1 & 8 & & 1 & 88 & 1 & 2 & 100 & 175 \\
\hline Semiskilled & & & & & & 4 & 15 & 70 & 11 & 100 & 27 \\
\hline Unskilled & & & 2 & 5 & 1 & 1 & 8 & 3 & 80 & 100 & 98 \\
\hline Total & 4 & 3 & 2 & 19 & 2 & 13 & 35 & 5 & 17 & 100 & 502 \\
\hline
\end{tabular}

mobile above the diagonal and the upwardly mobile below the diagonal. Unfortunately the small numbers in the cells for semiprofessionals and petty officials render analysis of these classes impossible.

A number of points warrant comment. First, the outflow percentages along the main diagonal reveal that the levels of persistence were somewhat higher for most classes in I9II-I9I9 than they had been in I902-I9II, selfemployed/small employers being an exception to the trend, and that downwards movement increased. Not all classes reflected the general trend to the same extent. Retention rates for white-collar and unskilled rose considerably while those for skilled rose slightly (as did persistence rates for other groups, but the small numbers involved suggest that little importance can be

Table 1.3. Male occupational mobility in Caversham Igo2-I9II, inflow percentages

\begin{tabular}{|c|c|c|c|c|c|c|c|c|c|c|}
\hline Column \% & 1911 & & & & & & & & & \\
\hline 1902 & LE & PR & SP & SE & $\mathrm{PO}$ & WC & SK & SS & US & Total \\
\hline Large employer & 95 & & & & 13 & & 1 & & & 5 \\
\hline Professional & & 64 & & 1 & & & 1 & & & 2 \\
\hline Semiprofessional & & & 56 & & & 2 & & & & 1 \\
\hline Small employer & & & & 72 & 13 & & 3 & & 1 & 15 \\
\hline Petty official & & & & & 63 & & 1 & & & 1 \\
\hline White-collar & 5 & 29 & 11 & 7 & & 94 & 1 & 4 & 2 & 16 \\
\hline Skilled & & 7 & 11 & 15 & & 2 & 87 & 4 & 3 & 35 \\
\hline Semiskilled & & & & & & 2 & 2 & 79 & 3 & 5 \\
\hline Unskilled & & & 22 & 5 & 13 & 2 & 5 & 13 & 90 & 20 \\
\hline Total & 100 & 100 & 100 & 100 & 100 & 100 & 100 & 100 & 100 & 100 \\
\hline $\bar{N}$ & 22 & 14 & 9 & 96 & 8 & 65 & 177 & 24 & 87 & 502 \\
\hline
\end{tabular}


Table I.4. Male occupational mobility in Caversham I9II-I9I9, outflow percentages

\begin{tabular}{|c|c|c|c|c|c|c|c|c|c|c|c|}
\hline Row \% & 1919 & & & & & & & & & & \\
\hline 1911 & $\mathrm{LE}$ & PR & SP & SE & $\mathrm{PO}$ & WC & SK & SS & US & Total & $N$ \\
\hline Large employer & 94 & & & & & 6 & & & & 100 & 33 \\
\hline Professional & 4 & 86 & & & & & 11 & & & 100 & 28 \\
\hline Semiprofessional & & & 100 & & & & & & & 100 & 12 \\
\hline Small employer & 1 & 1 & & 80 & 1 & 2 & 11 & 3 & 2 & 100 & 116 \\
\hline Petty official & 5 & & & & 90 & & 5 & & & 100 & 20 \\
\hline White-collar & & & 2 & 7 & 2 & 88 & & & 2 & 100 & 105 \\
\hline Skilled & & & & 2 & & 1 & 93 & & 3 & 100 & 266 \\
\hline Semiskilled & & & & 2 & & & & 90 & 8 & 100 & 49 \\
\hline Unskilled & & & & 1 & & 2 & 3 & 2 & 94 & 100 & 186 \\
\hline Total & 4 & 3 & 2 & 13 & 3 & 13 & 33 & 6 & 23 & 100 & 815 \\
\hline
\end{tabular}

Table I.5. Male occupational mobility in Caversham IgII-I9I9, inflow percentages

\begin{tabular}{|c|c|c|c|c|c|c|c|c|c|c|}
\hline Column \% & 1919 & & & & & & & & & \\
\hline 1911 & LE & PR & SP & SE & $\mathrm{PO}$ & WC & SK & SS & US & Total \\
\hline Large employer & 89 & & & & & 2 & & & & 4 \\
\hline Professional & 3 & 92 & & & & & 1 & & & 3 \\
\hline Semiprofessional & & & 86 & & & & & & & 1 \\
\hline Small employer & 3 & 4 & & 87 & 5 & 2 & 5 & 6 & 1 & 14 \\
\hline Petty official & 3 & & & & 82 & & & & & 2 \\
\hline White-collar & & & 14 & 7 & 9 & 90 & & & 1 & 13 \\
\hline Skilled & 3 & 4 & & 5 & 5 & 3 & 92 & 2 & 4 & 33 \\
\hline Semiskilled & & & & 1 & & & & 86 & 2 & 6 \\
\hline Unskilled & & & & 1 & & 3 & 2 & 6 & 92 & 23 \\
\hline Total & 100 & 100 & 100 & 100 & 100 & 100 & 100 & 100 & 100 & 100 \\
\hline$N$ & 35 & 26 & 14 & 107 & 22 & 102 & 269 & 51 & 189 & 815 \\
\hline
\end{tabular}

attached). The trend towards increased class stability, especially among those who sold their labour, was clearly evident. Nor does this pattern change if we analyse each possible subperiod within the years 1902-1919 (i.e., 1902I905, I905-I9II, I9II-I9I4, although only in 19I4-I9I9 did downwards exceed upwards mobility). Movement between the manual working classes and the higher non-manual classes was virtually nonexistent except for a small exchange between the professional and skilled classes.

The inflow rates, while different, confirm this picture of increased class stability. With the exception of large employers the higher non-manual classes remained eclectic in their recruitment patterns but became more stable. In 1902-191I the professionals and semiprofessionals recruited from 
skilled and even more vigorously from white-collar, reflecting the ease of movement between some metal trades and some branches of engineering and the fact that it was still quite common for accountants to be recruited from the ranks of book-keepers and clerks. It is clear, however, that it became harder for manual workers to enter the higher non-manual classes and less likely for higher non-manual men to become manual workers. The self-employed/small employers also became much more closed in the second period, eighty-seven per cent of their number in 1919 having been in the same class in I9II (compared with seventy-two per cent in the previous period). Skilled and unskilled became much less likely to break into the non-manual classes. In I9II-I9I9 the white-collar class was slightly more likely to have recruited from elsewhere but the size of the increase was scarcely significant. By and large the war period I9I4-1919 does not seem to have impacted upon recruitment in the way that it did on class retention.

A comparison of inflow/outflow rates for professionals over the two periods suggests that entry became more difficult over time. The increased emphasis on formal educational qualifications for the professions may explain this pattern. We need to be cautious, however, because the professionals, compared to other classes, continued to recruit quite eclectically largely, it seems, because of: (I) the weak barriers to movement between some branches of the metal trades and certain branches of engineering, and (2) the ease with which accountants could become higher managers (still a marked feature of New Zealand society). The exceptions help to prove the rule, however, for several "proto-professions" organized themselves in the period - dentists in 1904 and accountants in 1908, for instance - with the intention of achieving the professional status of doctors and lawyers. Sometimes these organizations required new entrants to have studied at university but often they organized their own examinations. Sometimes the two systems coexisted. A mania for state registration infected many occupations during this period, including plumbers and electricians (although those occupations did not aspire to professional status). The increased importance of school examinations in credentialling has been noted by several historians of education. ${ }^{4 \mathrm{I}}$

Analysis of the period 1919-1928 indicates that the trend towards closure did not continue (Table I.6 gives the outflow percentages and Table I.7 gives the inflow percentages). If we start by using the nine-class model, upwards mobility began to increase sharply in 1919-1922. The rate of

4I. T.W.H. Brooking, The History of Dentistry in New Zealand (Dunedin, NZ, 1980), ch. 3, provides the best overview. Not all succeeded, however; see Beryl Hughes, "Nursing Education: The Collapse of the Diploma of Nursing at the University of Otago, 1925-1926", New Zealand Journal of History, I2 (1978), pp. I7-33. See also J.D. McKenzie, "The Growth of School Credentialling, I878-1900", in Roger Openshaw and J.D. McKenzie (eds), Reinterpreting the Educational Past (Wellington, NZ, 1987), pp. 82-106, and Howard Baldwin, "The Social Origins and Destinations of Otago Boys' High Pupils, I862-1903”, (MA thesis, University of Otago, NZ, 1996). 


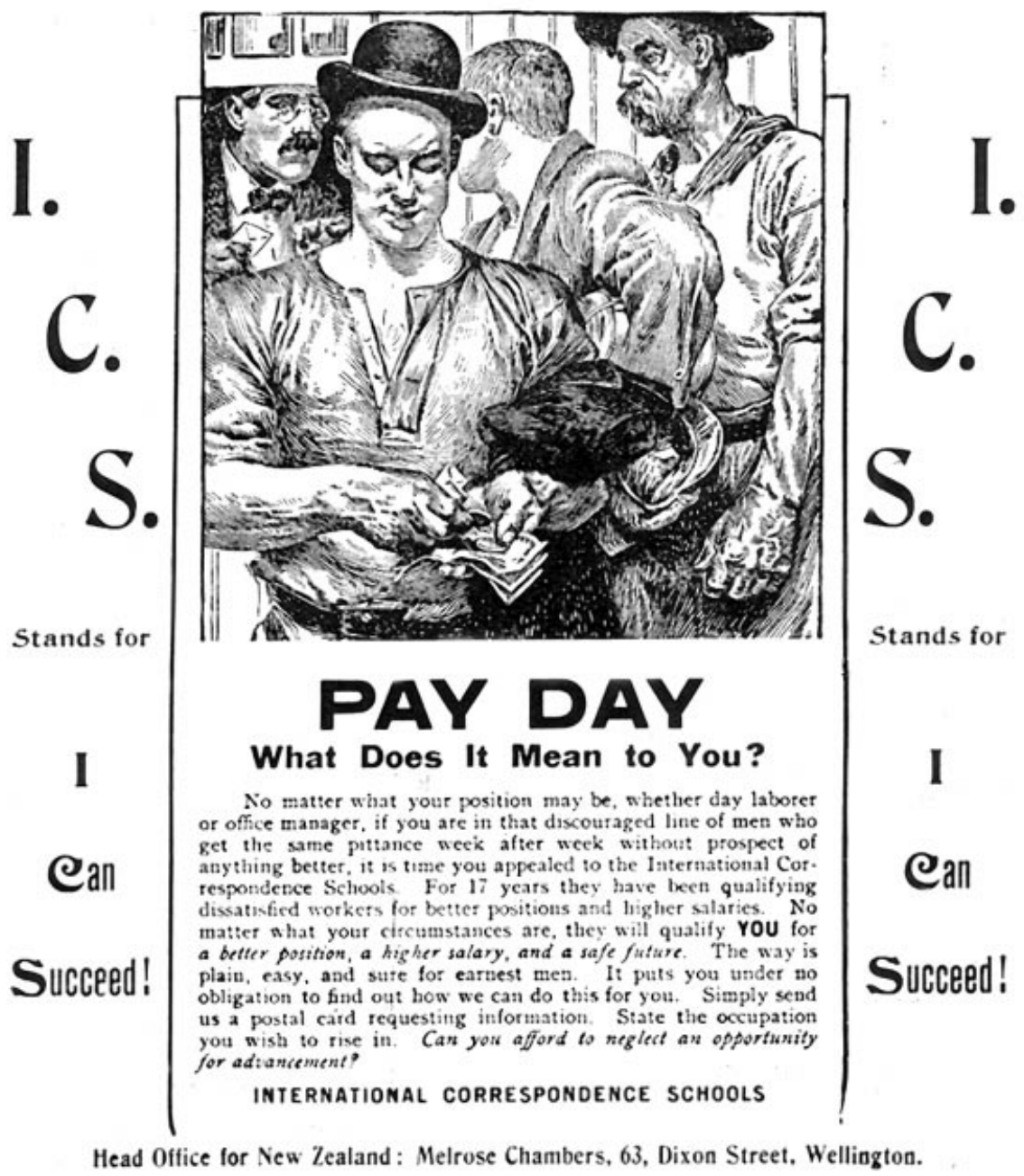

Figure 3. This advertisement was taken from the Railway Review, the journal of the Amalgamated Society of Railway Servants (ASRS). The state-owned railways employed large numbers of whitecollar as well as blue-collar workers. The International Correspondence Schools, an American mail-order institute which offered training for white-collar jobs, considered it worth advertising in the ASRS's journal, although there is little evidence that it proved terribly successful in New Zealand. In the rigros it became harder for manual workers to enter non-manual occupations, but by no means impossible. 
Table 1.6. Male occupational mobility in Caversham 1919-1928, outflow percentages

\begin{tabular}{|c|c|c|c|c|c|c|c|c|c|c|c|}
\hline Row \% & 1928 & & & & & & & & & & \\
\hline 1919 & LE & PR & SP & SE & $\mathrm{PO}$ & WC & SK & SS & US & Total & $N$ \\
\hline Large employer & 81 & 10 & 5 & & & & 5 & & & 100 & 21 \\
\hline Profe & 19 & 75 & & & & & 6 & & & 100 & 16 \\
\hline Semiprofessional & & 13 & 75 & & & 13 & & & & 100 & 8 \\
\hline Small employer & & & & 76 & & 4 & 10 & 1 & 8 & 100 & 72 \\
\hline Petty official & 5 & & & & 65 & 5 & 10 & & 15 & 100 & 20 \\
\hline White-collar & 6 & 4 & & 9 & 1 & 69 & 3 & 2 & 6 & 100 & 90 \\
\hline Skilled & & & 1 & 8 & 3 & 4 & 75 & 2 & 8 & 100 & 280 \\
\hline Semiskilled & & & & 2 & 2 & 6 & 23 & 28 & 38 & 100 & 47 \\
\hline Unskilled & & & 1 & 5 & 3 & 3 & 8 & 8 & 73 & 100 & 172 \\
\hline Total & 4 & 3 & 1 & 13 & 4 & 12 & 34 & 5 & 25 & 100 & 726 \\
\hline
\end{tabular}

Table 1.7. Male occupational mobility in Caversham 1919-1928, inflow percentages

\begin{tabular}{l|rrrrrrrrr|r}
\hline Column \% & 1928 & & & & & & & & & \\
\hline \multicolumn{1}{c|}{1919} & LE & PR & SP & SE & PO & WC & SK & SS & US & Total \\
\hline Large employer & 63 & 11 & 10 & & & & & & & 3 \\
Professional & 11 & 63 & & & & & & & & 2 \\
Semiprofessional & & 5 & 60 & & & 1 & & & & 1 \\
Small employer & & & & 59 & & 3 & 3 & 3 & 3 & 10 \\
Petty official & 4 & & & & 46 & 1 & 1 & & 2 & 3 \\
White-collar & 19 & 21 & & 9 & 4 & 72 & 1 & 6 & 3 & 12 \\
Skilled & 4 & & 20 & 23 & 29 & 13 & 84 & 14 & 12 & 39 \\
Semiskilled & & & & 1 & 4 & 3 & 4 & 37 & 10 & 6 \\
Unskilled & & & 10 & 9 & 18 & 6 & 6 & 40 & 70 & 24 \\
\hline Total & 100 & 100 & 100 & 100 & 100 & 100 & 100 & 100 & 100 & 100 \\
\hline $\boldsymbol{N}$ & 27 & 19 & 10 & 93 & 28 & 86 & 250 & 35 & 178 & 726 \\
\hline
\end{tabular}

upwards mobility exceeded all other three-year periods in the database and almost doubled the rate for the five war years. A similar pattern was evident on the three-class model. Downwards mobility also increased. In 1922-1928 the trend towards increased mobility accelerated. The ratio of upwards to downwards mobility was roughly three to two on both the nine- and threeclass models. Outflow and inflow rates also registered the dramatic change and the proportion occupationally persistent fell sharply for all classes and sometimes very sharply. Only the skilled, with a self-recruitment rate of eighty-five per cent, remained relatively impermeable. As in the previous periods no movement occurred between the two ends of the occupational structure, higher non-manual and unskilled/semiskilled, but otherwise 
considerable movement took place. ${ }^{42}$ Manual workers, in particular, enjoyed considerable opportunities for mobility into other classes. Although many skidded into the ranks of the unskilled many more moved upwards. The flow into the small employers/self-employed and white-collar was especially marked.

So far we have analysed absolute mobility rates. Absolute rates refer to the proportion of individuals who move, or do not move, from a class. Absolute rates, however, ignore changes in the size of the population and the shape of the occupational structure. Analysis of relative rates allows control for such changes. The relative mobility rate, in brief, indicates the relative probability that an individual will remain in the same class or move into a different class once the impact of demographic and occupational change has been removed. Relative mobility, defined statistically, is "that part of total mobility which is apparent after changes in the marginal distributions of tables have been filtered out" ${ }^{43}$ The marginal distributions of a mobility table express changes in the occupational structure and alterations in the demographic regime, whether caused by changing patterns of migration or shifts in the fertility rate. Where the margins of the mobility table are not equal, some mobility will simply reflect the fact that changes have occurred in the occupational structure or the shape of the population. Log-linear modelling is a standard technique used to distinguish between absolute and relative mobility. ${ }^{44}$

There is a vast array of log-linear models available to the researcher interested in social mobility, but we use log-linear modelling only to test if the patterns apparent from the analysis of absolute mobility are also reflected in the relative rates. The analysis makes use of two simple log-linear models, the first used by Erikson and Goldthorpe in a modern setting and the second, also developed by Erikson and Goldthorpe, used by Van Leeuwen and Maas in a historical setting. ${ }^{45}$ The first of these, the constant social fluidity model, requires three pieces of information for each individual: class origin, class destination, and the time period for all class movements. The model proposes that origins and time period are associated, that destinations

42. This finding confirms that reached by Pearson and Thorns, Eclipse of Equality, p. 23I, who found "a consistently high degree of closure at the top and bottom of the local stratification model" together with "fluidity over the middle ranges [...]".

43. Van Leeuwen and Maas, "Social Mobility in a Dutch Province", p. 620.

44. A log-linear model consists of a number of parameters which are combined to generate an estimated value for each cell in a cross-classification. The fit of the model can then be tested against the observed data. In general the object of log-linear modelling is to find a model which involves relatively few parameters but still matches the observed data well. If each parameter has theoretical significance then the model can identify the significant factors. For a full account of log-linear modelling with the Caversham data see Hamish James, "Log-Linear Modelling for Mobility Tables", Caversham Working Paper, 1997-4.

45. Erikson and Goldthorpe, Constant Flux, p. 87 and Van Leeuwen and Maas, "Social Mobility in a Dutch Province", p. 632. 
Table 1.8. Log-linear model results

\begin{tabular}{lcc}
\hline & Constant social fluidity & Uniform change \\
\hline Likelihood ratio chi squared & 181.70 & 99.97 \\
Degrees of freedom & 128 & 126 \\
Probability & 0.001 & 0.958 \\
\hline
\end{tabular}

and time period are associated, and that origins and destinations are associated. As "no three-way association is provided for in the model [...] it is also entailed that the level of association between class of origin and class of destination is constant across cohorts" ${ }^{46}$ The model, in other words, proposes that relative rates of mobility remain constant over time. The model of uniform change proposes that for all categories of origin and destination there may be some common trend towards greater or lesser fluidity in relative rates of mobility across the periods analysed.

Table I. 8 compares the performance of the two models. ${ }^{47}$ The constant social fluidity model does not fit the Caversham data, but the model of uniform change gives a very good fit, with a probability of 958. Examination of the parameters of the model of uniform change indicate that there was no significant change between the first two periods, I9O2-I9II and I9II1919, but that the trend tended towards greater openness in the 1920s. ${ }^{48}$ This said, however, it would be a mistake to assume, as some scholars do, that relative rates make absolute rates redundant. Both measure an important aspect of social structure.

\section{MOBILITY RATES AND VOTING PATTERNS}

Even on first glance the most striking (if unexpected) fact is the close fit between Caversham's mobility levels and the nation's political history. Against a background increasingly dominated by industrial unrest and the labour movement's quest to form a united political party of the "left", the Liberals governed between 1902-1912 while conservative Reform governed between 1912 and 1928 . The shift in the trend which occurred in 1919-1928 might at first seem to contradict this finding, but Reform formed a coalition with the Liberals from I9I5 until I9I9 and then adopted several new policies designed to block independent Labour's political advance by increasing

46. Erikson and Goldthorpe, Constant Flux, pp. 87-88.

47. For both models, O.I was added to all cell frequencies.

48. The parameter estimate comparing the trend of the third decade (1919-1928) with that of the first (I902-I9II) is -0.260 , the standard error is 0.054 . Parameter estimates are significant if their value is at least twice that of the standard error (Van Leeuwen and Maas, "Social Mobility in a Dutch Province”, p. 634) and a negative value indicates a trend towards greater openness (Erikson and Goldthorpe, Constant Flux, p. 92). The parameter comparing the second decade (I9II-I9I9) with the first is also negative, but insignificant. 
opportunities for social mobility and home ownership. In this Reform largely succeeded, although the warring factions of the labour movement finally achieved unity in the period $1916-1922 .{ }^{49}$ As there is nothing in the literature on mobility to suggest such a relationship we focused first on the apparent fit between the decrease in the absolute rates of mobility in I9II-I922 and political developments. On a priori grounds it seemed more likely that changes in the occupational structure caused by World War I might explain the increased stability of the second period, for roughly forty-six per cent of New Zealand men between the ages of eighteen and forty years old served in the armed forces. ${ }^{50}$

In order to check this the two subperiods, I9II-I9I4 and 19I4-I9I9, were disaggregated. The war period itself is notable for being the only one of six interelection periods where downward mobility exceeded upwards mobility but I9II-I9I4 contributed more than I9I4-I9I9 to the greater class cohesion of I9II-1919. In other words the level of class stability in I9II-I9I4 was appreciably higher than it was during the war (when Reform and Liberal combined to form a national coalition). Indeed, the level of class stability was highest in I9II-1914, Reform becoming government in 1912, and the war years (I9I4-I9I9) coincided with, and possibly helped create, a more fluid situation characterized by the highest downwards rate of any subperiod in 1902-1928. ${ }^{51}$ Apparent coincidences abound. The high downwards rate coincided with wartime industrial unrest and the formation of a united and socialist Labour Party in I9I6. The I9II-I9I4 period, as W.H. Oliver might have predicted, coincided with the worst years of industrial unrest (spearheaded by the syndicalist "Red" Federation of Labour). ${ }^{52}$ Although the revolutionary industrial union movement had no visible presence in Caversham, in the elections of I9II and I9I4 Socialist and Labour candidates did well in Dunedin and several once-conservative trade unions adopted industrial unionism. In the 1919 elections the newly-formed Labour Party

49. For an excellent overview of Reform in office see Miles Fairburn, "The Farmers Take Over (1912-1930)", in Keith Sinclair (ed.), The Oxford Illustrated History of New Zealand (Auckland, NZ, 1990), pp. I85-210. For Labour's failure to increase its proportion of the vote after I919 see Fairburn, "Why Did the New Zealand Labour Party Fail to Win Office [...]?", pp. IoI-I24. 50. Paul Baker, King and Country Call: New Zealanders and the Great War (Auckland, NZ, 1988), p. 238. It is impossible to provide an equally precise figure for Caversham but enthusiasm for the war was marked; Olssen, Building the New World, pp. I44, 214-217.

5I. Our data for I9II are for the end of the year - i.e. the electoral rolls. This inconclusive election was followed by six months of political uncertainty under a "conservative" and inactive Liberal government. In June I9I2 Reform took office. See Len Richardson, "Parties and Political Change", in Rice (ed.), Oxford History, ch. 8.

52. In his brilliant essay, "Reeves, Sinclair and the Social Pattern", in Munz (ed.), The Feel of Truth, pp. 163-180, Oliver argued that class had been less important than perceived obstacles to upwards mobility in generating radical movements. 
increased its share of the local vote but in subsequent elections it lost ground..$^{53}$

There is nothing in the theoretical literature to suggest that differing absolute mobility levels, for the relative rate did not differ over the first two periods, translate directly into consciousness and action. No other study of social mobility has found such a precise relationship between political events and the changing level of social mobility; (many studies, of course, have ignored the possibility). The relationship is less simple than it seems, however. ${ }^{54}$ During the I89os the electorates which included parts of Caversham became Liberal-Labour strongholds but Labour candidates did increasingly well in the period 1908-1914. When Labour candidates first contested the Lib-Lab seats in I905 they polled poorly. In I9II, however, Labour won forty-five per cent of the vote in Dunedin South and in I9I4 over forty-nine per cent in Dunedin Central (the two electorates which included Caversham). In the 1919 election Labour candidates, now standing for a more militantly socialist party, narrowly failed to capture both seats. Although Caversham's voters did not greatly increase their support for Labour candidates in the period 1914-1919, which one might expect if voters were responding to the increased rigidity of the class structure and declining opportunities for upwards social mobility, it is possible that increased social rigidity made it easier for Labour to move sharply left while consolidating its hold on almost half the voters.55 Many who first voted Labour in 1905 or 1908 merely wanted to make the Lib-Lab government more responsive to the desires of organized labour but over the next period Labour, constantly moving left, acquired a loyal and large following. Issues relating to mobility, especially land and education policies, were certainly widely debated and the three main parties had very different positions. The growth of inequality, symbolized on the left by such symbolic figures as "Mr Fat", a grasping capitalist, was also a major issue during the period $1914-1919 .{ }^{56}$

53. Olssen, Building the New World, pp. 20I-225 and Shaun Ryan, "Men of Metal: The Amalgamated Society of Engineers in Otago, I874-I922", (M.A. thesis, Otago University, NZ, 1996), ch. 6. As Olssen explained in A History of Otago (Dunedin, NZ, 1984), ch. 8, the local labour movement's success in using political power acted as a prophylactic against syndicalism and revolutionary industrial unionism.

54. If mobility chances were age-specific, as some studies have concluded, then part of the increased rigidity would reflect that impact of the I47 men in our sample who were residents of Caversham throughout the period $1902-1928$, and that a large number of young men were removed for the war. Even were this the case - i.e. that mobility chances reflected age - the impact of increased rigidity remained.

55. In the more industrial areas the Labour Party polled most strongly; for a fuller discussion see Olssen, Building the New World, pp. 207-212, 214-221.

56. For political developments in New Zealand see also B.S. Gustafson, Labour's Path to Political Independence: The Origins and Establishment of the New Zealand Labour Party, I900-I9I9 (Auckland, NZ, I980), chs 8-I2. 


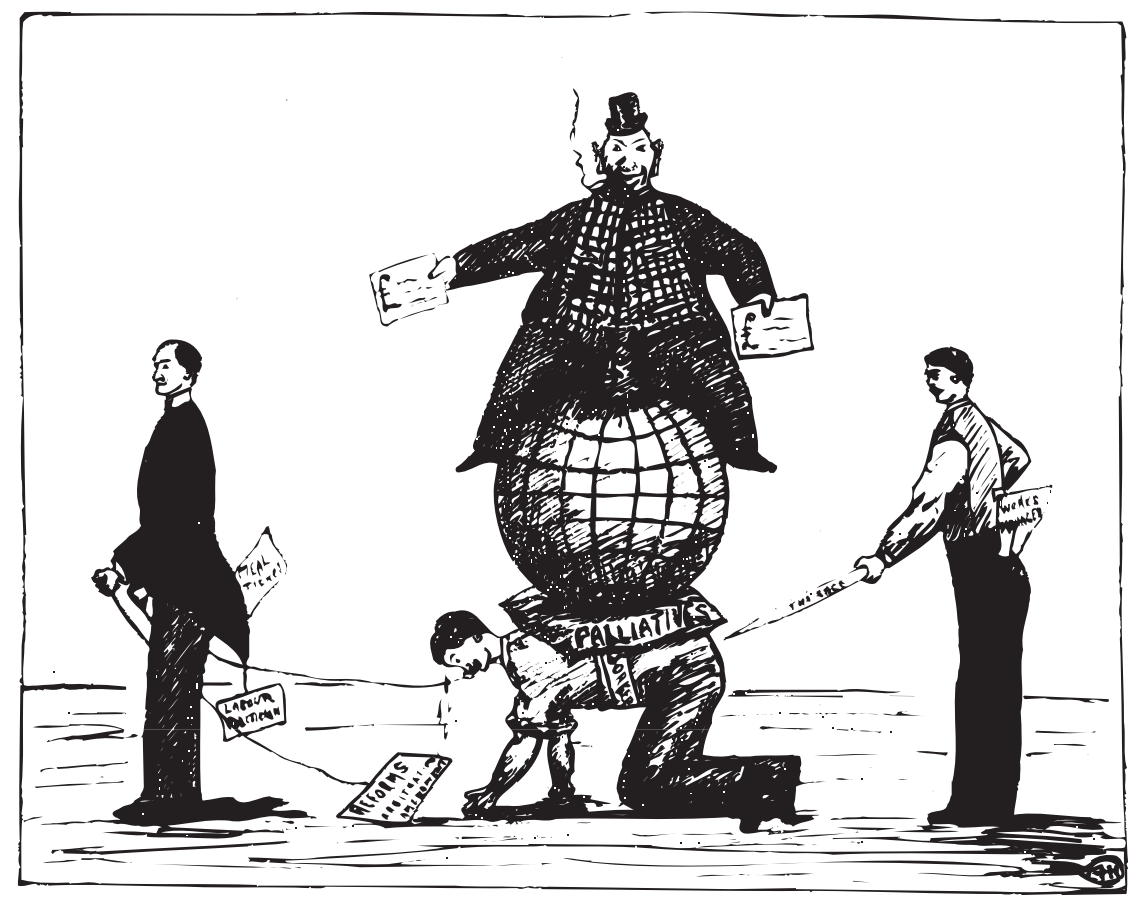

HOW LONG?

Figure 4. Cartoon from the Industrial Unionist, I May I9I3. It portrays a patient "wage-slave" carrying a bloated capitalist on his back. In this period that bloated capitalist was generally known as "Mr Fat". Such a vision made upwards social mobility irrelevant; indeed in this period many revolutionaries from comfortable middle-class backgrounds actually joined the proletariat in order to aid the revolution.

While detailed analysis complicates the initial finding, the suspicion remains that government policies had an impact on mobility levels and that voters may well have chosen their party on the basis, at least in part, of its record on issues perceived as relevant to mobility prospects. The increase in overall mobility which began in 1919-1922 and accelerated in 1922-1928, making the third decade in this study the most open, whether in absolute or relative terms, confirms this conclusion. Labour's proportion of the vote dropped locally in 1922 and the party failed to regain the lost ground in either 1925 or 1928. If mobility bears centrally on class formation, class structuration, and the potential for class action, as several scholars have concluded, then the high rates of worklife mobility in 1919-1928, and the return to a pattern where upwards movement substantially exceeded downwards movement, may have helped blunt Labour's advance. Not only did Labour fail to increase its share of the vote but the union movement lost 
ground both in membership and bargaining power. This account captures only part of the story, however, for Caversham and Dunedin did not enjoy economic growth in the postwar period and the government's main policies for increasing opportunity would not have been particularly apparent to the voters in our database. Land and loans for soldiers to set themselves up as farmers or small proprietors, while important nationally, had little impact within Caversham. Reform's parallel policy of making credit easily available to prospective home-owners might have had an impact locally but our database cannot address the question of home ownership. Home ownership, however, is not unimportant as a dimension of the opportunity structure. ${ }^{57}$

\section{CAVERSHAM'S MOBILITY RATES IN INTERNATIONAL CONTEXT}

Such an analysis immediately raises the issue discussed earlier: what is a "high" rate or a "low" rate? The question cannot be answered from absolute rates in the abstract. It is instructive to compare mobility in Caversham with mobility in other cities and towns, however, as low levels of mobility indicate social closure which in turn suggests demographic class formation and the potential for the recognition of shared political interests to become an important factor in politics. Most comparable studies have assumed the centrality of the divide between non-manual and manual occupations, sometimes known as "white-collar" and "blue-collar", which imputes a universal preference for non-manual work and ignores the possible significance of small employers/self-employed..$^{58}$ Although neither assumption holds true for Caversham it is simple enough to reorganize the Caversham data into comparable categories in order to compare Caversham's mobility rates with the rates reported for other cities and towns. ${ }^{59}$ Although these cities vary considerably in size, growth rates, and economic function, Thernstrom's conclusion that "the post-I850 Boston pattern was manifest in a wide range of other cities" emphasizes the value of the comparison; (we include some

57. Fairburn, "Why Did the New Zealand Labour Party Fail to Win Office [...]?", pp. I22-I24, concluded that Labour's electoral fortunes were in inverse ratio to the Reform government's expenditure on housing. For an incisive analysis of the impact of home ownership on stratification see Pearson and Thorns, Eclipse of Equality, pp. 67-70, 86-95, I25-I28, and 244-247. We have data for home ownership in 1937, however, when fifty-six per cent of all homes were owner-occupied. 58. Hartmut Kaelble, Historical Research on Social Mobility: Western Europe and the USA in the Nineteenth and Twentieth Centuries (London, 198I), provides a useful summary and, on p. 4I, a brief critique of the assumed importance of the non-manual/manual divide.

59. Higher white-collar or higher non-manual consist of employers/higher managerial, professionals, and semiprofessionals, while lower white-collar or lower non-manual usually comprise petty proprietors, officials and petty executives, and white-collar, while the three manual classes skilled, semiskilled and unskilled - constitute the "manual". The location of boundaries has proved contentious, usually with regard to routine clerical workers, but we agree with Kaelble that value exists in comparing findings for different nations even though some classifications differ. 
Table I.9. Worklife movement over the non-manual/manual divide in fifteen urban areas, I880-1930, expressed as percentages (Caversham, of persisters) ${ }^{60}$

\begin{tabular}{llcc}
\hline Decade & Place & Upwards (\%) & Downwards (\%) \\
\hline $1880-1890$ & & 22 & 7 \\
& Atlanta, USA & 21 & 2 \\
& Omaha, USA & 12 & 12 \\
& Boston, USA & 8 & 4 \\
Bochum, Germany & & no figure \\
& Oskersom, Sweden & 10 & 2 \\
$1890-1900$ & Eindhoven, Netherlands & 8 & 6 \\
& Omaha, USA & 23 & 12 \\
1910 & Graz, Austria & 16 & 7 \\
& Caversham 1902-1911 & 9 & 10 \\
& & & 13 \\
& Boston, USA & 22 & 4 \\
& Los Angeles, USA & 16 & 11 \\
$1920-1930$ & Norristown, USA & 8 & 6 \\
& Caversham, 1911-1922 & 7 & 14 \\
& Eindhoven, Netherlands & 14 & 8 \\
\hline
\end{tabular}

figures for periods in which we lack data for Caversham because they underline the range of results possible for any one city and show the persistently high rates achieved by American cities). ${ }^{61}$

In the first two periods for which we have comparative data, Caversham falls clearly at the bottom of the scale, together with Norristown, a town with one industry, a steel mill, which was larger than any industrial factory in New Zealand; (as Thernstrom pointed out, Norristown deviated considerably from the American pattern). ${ }^{62}$ Although we have fewer towns in Europe it is again striking that Caversham falls at the bottom of the range

6o. Kaelble, Social Mobility, Table 3.2, p. 37. The American data have been taken from Thernstrom, Other Bostonians, p. 234; R.J. Hopkins, "Occupational and Geographic Mobility in Atlanta, I870-1896", Journal of Southern History, 34 (I968), p. 205; Howard Chudacoff, Mobile Americans: Residential and Social Mobility in Omaha I880-I920 (New York, 1972); and the data for Eindhoven, from Henk van Dijk, Joop Visser and Emmy Wolst, "Regional Differences in Social Mobility Patterns in The Netherlands and Between I830 and 1940", Journal of Social History, I7 (1983/84), p. 447.

6I. Thernstrom, Other Bostonians, pp. 235-24I, confirmed this remarkable similarity by investigating more fully the mobility pattern in "the country's fourth largest metrfiolis and a city with only 20,000 inhabitants". He concluded that high labour turnover and similar occupational structures probably explain the phenomenon.

62. See Sidney Goldstein, Patterns of Mobility, I9I0-1950: The Norristown Study (Philadelphia, PA, 1958) and Thernstrom, Other Bostonians, p. 236. 
(the study of Eindhoven did not include all classes and is the least comparable). Those who aspired to non-manual jobs may have left, ${ }^{63}$ but it also seems likely, given what is known about Caversham's manual workers, that they did not want non-manual jobs. It may seem puzzling that they remained immune to a supposedly universal contagion but the answer may lie with their British origins. Unfortunately there are no comparable studies of mobility in Britain but the literature on the aspirations of skilled British workers suggests that manual workers in Caversham could aspire to the British artisan's dream: a high standard of living, manly independence, control of the labour process, and respectability. ${ }^{64}$ The low level of movement from manual to non-manual jobs may simply reflect contentment or disdain for the office-bound "pen-pushers" who dominated the lower reaches of the "non-manual" class. ${ }^{65}$ Given the propensity of the petty official class, and to a lesser extent white-collar, to recruit from the unskilled, this disdain may have had other dimensions in Caversham.

Thernstrom's analysis of Boston provides us with our most useable American comparison, for although he used a sample he analysed the period 1910-1920. This can be taken as equivalent to our 191I-1919 period. Boston was substantially larger than Dunedin, not to mention Caversham, but the fact that mobility patterns and rates were remarkably similar across a number of American cities and towns, regardless of their size or economic purpose, provides ample justification. ${ }^{66}$ The comparison between Boston and Caversham is certainly very suggestive. Boston's overall worklife mobility rates were considerably higher than Caversham's. ${ }^{67}$ In order to make the comparison more precise, however, we collapsed our nine classes into Thernstrom's five classes (high non-manual, low non-manual, skilled, semiskilled, and unskilled). ${ }^{68}$ If we compare Thernstrom's findings for I9IOI920 with ours for I9OI-I9II and I9II-I9I9 we find that, with the exception

63. This issue will be investigated in a subsequent paper but requires complex record-linking. Preliminary work suggests, however, that if leavers wanted non-manual jobs they failed to obtain them by leaving; see Brian Heenan, Sarah Johnsen and Hamish James, "Extra-Urban Migration", Caversham Working Paper, 1997-5.

64. The literature is summarized in Kaelble, Social Mobility, pp. 43-44. For British skilled workers see Geoffrey Crossick, An Artisan Elite: Kentish London 1840-I880 (London, I978), p. IO5 ff., and Robert Q. Gray, "Thrift and Working-Class Mobility in Victorian Edinburgh", in A.A. MacLaren (ed.), Social Class in Scotland (Edinburgh, 1976), pp. I28-I42. For the prevalence of socially-mixed residential areas and high levels of home ownership see Clyde Griffen, "The New World WorkingClass Suburb Revisited: Residential Differentiation in Caversham, New Zealand", forthcoming. 65. Although one must be cautious about using conclusions based on another period, the debate over embourgeoisment in the 196os concluded that highly-paid clerical workers retained workingclass values and mores and had no desire to leave the working class; see David Lockwood, Blackcoated Worker (London, 1969), pp. 194-198 for a comparison of bank clerks and railway clerks. 66. Thernstrom, Other Bostonians, p. 235.

67. Ibid., Table 4.4, p. 55 .

68. Ibid., Table 4.5, p. 57 and for his classification of occupations pp. 289-302. We disaggregated his "low white-collar", which includes "petty proprietors, managers and officials", but otherwise ignored the handful of instances where we had classified small occupations differently. 


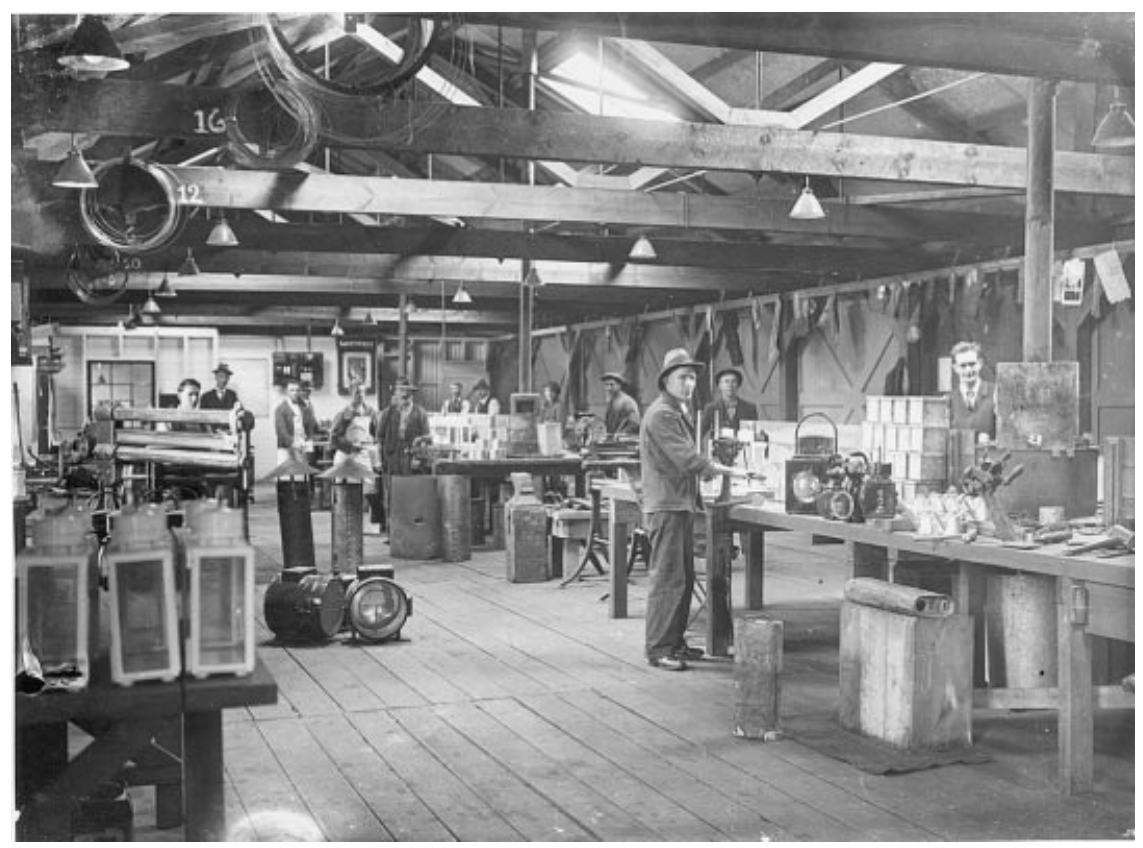

Figure 5. A Caversham manual worker could aspire to the British artisan's dream, not to mention the chance of owning his own house and enough land for a garden. The photographer, Percy Godber, a turner in the railway workshops, has skilfully captured the tinsmiths' sense of craft, pride and respectability. Most of the men are wearing suits and ties.

of the high non-manual, each of the five classes in Caversham was definitely more stable (i.e. lower social mobility and higher occupational persistence). The high non-manual, not surprisingly, was fairly cohesive in both places but thereafter the differences multiply.

A comparison of the low non-manual in Caversham I902-I9II with the same class in Boston 1910-1920 reveals comparable levels of class stability but in the next subperiod Caversham's low non-manual became much more cohesive. If we compare the skilled in the two places the difference is smaller but marked. The most dramatic single comparison, however, shows that the unskilled in Caversham were much more stable than the same class in Boston. The direction of change is even more striking. In Boston the unskilled became markedly less stable between 1890 and 1920 whereas in Caversham this class became considerably more stable in the first two periods. Although Caversham's unskilled became substantially more open in 1919-I928 the class retention index of seventy-three per cent was still much higher than Boston's thirty-nine per cent. If we next look at the semiskilled in both places in the rios we find the same trend, muted. Boston's unskilled, and to a lesser extent semiskilled, lived in a much more open 
society than Caversham and one becoming more open. By contrast, Caversham's class structure at the lower levels became more rigid over the period 1902-1919 and while it became more open in the third period it remained much more closed than Boston's. More striking still was a marked swing among Caversham's skilled away from upwards mobility and towards downwards mobility. In the third period the skilled became more mobile again, and upwards exceeded downwards movement, but the overall index of cohesion remained higher than in Boston and downwards movement much more common. If we compare social mobility in Caversham I9II-I919 and Boston I9IO-1920, both within the manual working class and between the manual working class and the lower white-collar, we find much less social mobility in Caversham. Nor does the picture change if we look only at movement from skilled to lower white-collar. Table 2.o, Mobility in Caversham and Boston, points up the comparisons. ${ }^{69}$

The absence of data on age for the Caversham men reduces the reliability of the comparison. Thernstrom's data, taken from census enumerators' books, allowed a subsequent analysis of the ages of his sample whereas the Caversham men were between twenty-one years old and retirement or death. Assuming that men became less likely to be upwardly mobile as they moved into their forties, then it is possible that the differences in the class persistence rates between Boston and Caversham are much smaller than the figures in Table I.9 indicate. This is especially the case where the difference was less than twenty per cent. The difference in the class persistence rates for the unskilled is so large, however, that it is very unlikely that it would disappear even if we had age data for the Caversham men. ${ }^{70}$ Record linkage provides age data for about fourteen per cent of our sample (seventy individuals for I902-I9II, II5 for I9II-I919, and ninety-one for 1919-1928) and indicates that the different rates are not a function of different age structures. Our subsample, while too small to warrant extensive analysis, does tend to show that for each of the three time periods the mobile members of our age subsample are on average younger than the immobile members. The difference is most dramatic in I9O2-I9II when mobile individuals had an average age of twenty-seven years and immobile individuals had an average age of thirty-eight years. In the later periods the difference is smaller, the average ages for I9II-I9I9 being thirty-one and thirty-seven, and for 1919-1928, thirty-five and forty.

69. We are grateful to Emeritus Professor Clyde Griffen, who recognized the possibility of making this comparison and identified the critical differences.

70. J. Morgan Kousser, Gary M. Cox, and David W. Galenson, "Log-Linear Analysis of Contingency Tables: An Introduction for Historians with an Application to Thernstrom on the 'Floating Proletariat'", Historical Methods, I5 (I982), pp. 152-169, re-analysed Thernstrom's age data and highlighted the important relationship between age and a man's place in the occupational structure. 
Table 2.o. Occupational mobility in Caversham and Boston: Recategorization of Caversham occupational groups into Thernstrom's categories (Table 4.5, p. 57)

(a) Classifying Caversham nine-class scheme into Thernstrom's five classes

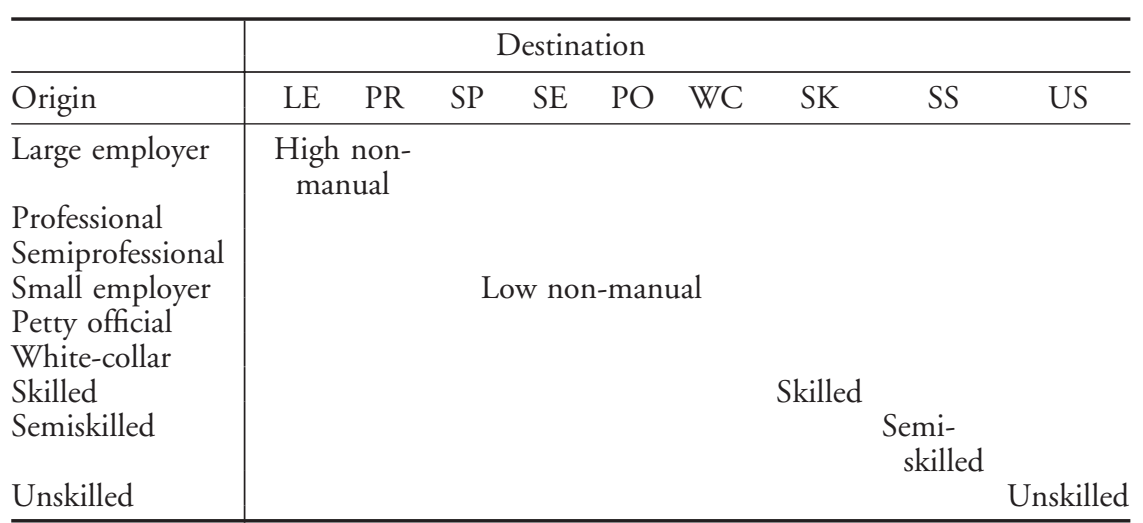

(b) Comparison of Boston and Caversham

\begin{tabular}{|ccc|}
\hline & Boston 1910-1920 & \\
Caversham & Caversham & Caversham \\
$1902-1911$ & $1911-1919$ & $1919-1928$ \\
\hline
\end{tabular}

\begin{tabular}{|c|c|c|c|c|c|c|c|c|c|c|c|c|c|c|c|}
\hline Row \% & \multicolumn{3}{|c|}{$\begin{array}{l}\text { High non- } \\
\text { manual }\end{array}$} & \multicolumn{3}{|c|}{$\begin{array}{l}\text { Low non- } \\
\text { manual }\end{array}$} & \multicolumn{3}{|c|}{ Skilled } & \multicolumn{3}{|c|}{ Semiskilled } & \multicolumn{3}{|c|}{ Unskilled } \\
\hline $\begin{array}{l}\text { High } \\
\text { non-manual }\end{array}$ & 88 & $\begin{array}{l}90 \\
92\end{array}$ & 92 & 6 & $\begin{array}{l}7 \\
3\end{array}$ & 3 & 6 & $\begin{array}{l}0 \\
5\end{array}$ & 5 & 0 & $\begin{array}{l}3 \\
0\end{array}$ & 0 & 0 & $\begin{array}{l}0 \\
0\end{array}$ & 0 \\
\hline $\begin{array}{l}\text { Low } \\
\text { non-manual }\end{array}$ & 3 & $\begin{array}{r}10 \\
1\end{array}$ & 6 & 89 & $\begin{array}{l}79 \\
91\end{array}$ & 79 & 5 & $\begin{array}{l}2 \\
6\end{array}$ & 6 & 1 & $\begin{array}{l}7 \\
1\end{array}$ & 2 & 2 & $\begin{array}{l}3 \\
2\end{array}$ & 7 \\
\hline Skilled & 1 & $\begin{array}{l}2 \\
1\end{array}$ & 0 & 9 & $\begin{array}{r}21 \\
3\end{array}$ & 15 & 88 & $\begin{array}{l}66 \\
93\end{array}$ & 75 & 1 & $\begin{array}{r}10 \\
0\end{array}$ & 2 & 2 & $\begin{array}{l}1 \\
3\end{array}$ & 8 \\
\hline Semiskilled & 0 & $\begin{array}{l}3 \\
0\end{array}$ & 0 & 4 & $\begin{array}{r}20 \\
2\end{array}$ & 11 & 15 & $\begin{array}{l}5 \\
0\end{array}$ & 23 & 70 & $\begin{array}{l}65 \\
90\end{array}$ & 28 & 11 & $\begin{array}{l}8 \\
8\end{array}$ & 38 \\
\hline Unskilled & 0 & $\begin{array}{l}0 \\
0\end{array}$ & 0 & 9 & $\begin{array}{r}18 \\
2\end{array}$ & 11 & 8 & $\begin{array}{l}8 \\
3\end{array}$ & 8 & 3 & $\begin{array}{r}36 \\
2\end{array}$ & 8 & 80 & $\begin{array}{l}39 \\
94\end{array}$ & 73 \\
\hline
\end{tabular}

The difference between the class structures of Caversham and Boston are entirely plausible. First, in Dunedin and New Zealand the union movement strengthened its position considerably in the first two decades, both among the skilled and the unskilled, whereas the American union movement began to falter, then lost momentum. Although New Zealand unions lost a little ground in the I920s they did not lose as much ground as their American 
counterparts. Moreover, in New Zealand the growing power of skilled unions enabled them to enforce their power within the labour process whereas in the United States many skilled unions lost power as their control of the labour process was successfully attacked. One reason why this attack succeeded alerts us to a second fundamental difference which helps to explain the dramatic difference in the level of class persistence between the two places. Non-British immigrants poured into the United States from I880 until I9I4 (first and second generation immigrants comprised seventyfour per cent of Boston's population in $19 \mathrm{IO}$, most of them non-British). ${ }^{71}$ They entered unskilled occupations in a tidal wave, deepening the gulf between skilled and unskilled and pushing older immigrants into whitecollar and supervisory jobs (a sort of escalator effect)..$^{72}$ Simultaneously, in the United States, the growth of mass production in several industries created a vast market for semiskilled machine operators. Minority groups, whether blacks from the south or peasants from southern and eastern Europe, helped employers to defeat the skilled. ${ }^{73}$ These immigrant communities, besides, were large enough to create sizeable opportunities for their members to establish businesses which specialized in meeting the needs of their own people. ${ }^{74}$ With the exception of Irish Catholics and Maori there were no sizeable ethnic/racial minorities within New Zealand's labour markets and the Maori, in this period, were overwhelmingly rural. ${ }^{75} \mathrm{New}$ Zealand's powerful labour movement fulfilled the American Federation of Labor's dream and made the country a closed shop for skilled British workers. ${ }^{76}$

\section{CONCLUSION}

As Thernstrom's critics pointed out, it is not clear whether the different levels of rigidity in the various classes were visible to contemporaries. Nor

7I. Thernstrom, Other Bostonians, p. II3.

72. For a stimulating comparative analysis see Jürgen Kocka, White Collar Workers in America, I890-1940: A Socio-Political History in International Perspective, translated by Maura Kealey (London and Beverly Hills, CA, I980).

73. This point has been well made by Herbert Gutman in his seminal essay, "Work, Culture, and Society in Industrializing America, I8I5-1919”, American Historical Review, 78 (1983), pp. 53I-588. 74. There is an enormous literature relevant to the generalizations made in this paragraph and I have traversed the issues more fully in "The Case of the Socialist Party That Failed, or Further Reflections on an American Dream”, Labor History, 29 (1988), pp. 4I6-449.

75. The Irish Catholic experience in the New Zealand labour market has been almost ignored, although generalizations abound; see Donald H. Akenson, Half the World from Home: Perspectives on the Irish in New Zealand, I860-I950 (Wellington, NZ, 1990), ch. I, who argues from census data that the Irish were not segmented within unskilled occupations.

76. See Olssen, "The New Zealand Labour Movement and Race", in Marcel van der Linden and Jan Lucassen (eds), Racism and the Labour Market: Historical Studies (Berne, 1995), pp. 373-393. See also Alexander Saxton, The Indispensable Enemy: Labor and the Anti-Chinese Movement in California (Berkeley, CA, 197I). 
can one infer the degree of class consciousness from structural variables. What the "real" rates meant to contemporaries requires knowing the expectations of the two communities. One can safely assume that unskilled men in Caversham had no idea that they were disadvantaged compared to unskilled Bostonians, or that they would have cared had they known, and they may well have been entirely happy with the level of opportunity available. This well-known slippage between structure and the meanings assigned to structure by the historical actors, the gist of the hermeneutic critique, does not invalidate structural analyses. ${ }^{77}$ Structural change can only be used in defining one aspect of a more complex social-cultural world and its meaning must be identified through contemporary perceptions. Those perceptions bore the imprint of the hopes and desires of British artisans and developed in the I89os to emphasize mutual aid, local autonomy, apprentice-based crafts and control of the job. Armed with this strong sense of the worker's just entitlements, Caversham's workingmen increasingly resorted to political action and built both strong unions and a powerful political movement. ${ }^{78}$ As the Griffens noted, however, "the individual drive for success" should not be considered incompatible with "occasions [...] [of] solidarity". ${ }^{79}$ There is plenty of evidence that individualistic and collectivist attitudes and habits coexisted among Caversham's workers. The desire for social mobility, or merely a belief that opportunities ought to be available, did not preclude a willingness to support collectivist strategies any more than casting a vote for a Labour candidate, or even striking, precluded a desire to improve one's personal position. Becoming self-employed or a small master was still normal in Caversham. Egalitarianism, the dominant cultural pattern, accommodated the tension between individuality and solidarity, defining the socially acceptable forms for the pursuit of individual goals. ${ }^{80}$

Given the coexistence of individual and collective strategies and aspirations it must be considered significant that the congealing class structure at the lower reaches was so closed at roughly the period when industrial conflict reached unprecedented levels (1908-1920) and a Labour Party preaching revolutionary socialism established itself securely in urban areas (1904-I922). These national developments were echoed in Caversham and Dunedin, the local unions becoming increasingly class-conscious, especially from I9I3 onwards, while the once-aloof Dunedin Labour party moved far enough "left" to affiliate to the New Zealand Labour Party on its formation

77. Savage, "Social Mobility and the Survey Method", in Bertaux and Thompson (eds), Pathways to Social Class, pp. 316-32I, provides a valuable discussion.

78. See Olssen, Building the New World, especially ch. Io.

79. Griffens, Natives and Newcomers, pp. xii-xiii.

8o. For egalitarianism see Olssen, Building the New World, pp. 246-253 and for the earlier point about the normality of becoming a petty proprietor see ch. 3. See also Pearson and Thorns, Eclipse, pp. 72-73, IIO-III, 236-244. 
in 1916 while retaining the loyalty of supporters. The Reform government's hostility to the militant unions may have given local workers even stronger reasons for voting Labour, although they disapproved of most militant tactics. It seems just as likely that their perception of Reform as hostile to workingmen reflected their sense that it had become harder for workingmen to enter non-manual jobs. One did not have to desire upwards mobility for oneself to resent the increased difficulty, the discrimination against members of one's own class, and the tendency of the rich to flaunt their power and wealth.

Socialist and Labour political rhetoric of the period is steeped in such resentments. The desire to nationalize all productive land and all large industries reflected not only a social-democratic critique of private property but an older fear that private wealth, unchecked, caused opportunities for others to shrink. Nor is it irrelevant to note that the growing use of collectivist strategies in the period $1908-1920$ alienated petty proprietors and whitecollar workers, despite their eclectic recruitment patterns. They now moved to define themselves culturally and politically as apart from the "working class". The dramatic increase in opportunities for upwards mobility which occurred in the postwar decade did not alter these trends but made it harder for Labour to enlarge its constituency despite population growth. This process of differentiation, tentatively inferred from political behaviour in Building the New World, appears to be confirmed by using mobility patterns to analyse social structure..$^{8 \mathrm{I}}$ It is not only, as Erikson and Goldthorpe noted, that the more a social class recruits from its own ranks, and the less easy it is for its members to achieve upwards mobility, the more likely it is to be socially and culturally cohesive, and the more likely it is to engage in classbased collective action. The evidence from Caversham also suggests that voters were not unconscious of the shifting pattern of class rigidity and opportunity.

8I. Olssen, Building the New World, chs 7 and 8. For political developments in New Zealand see also Gustafson, Labour's Path to Political Independence, and for the union movement, Olssen, The Red Feds. 
